\title{
EXPERIENTIAL-BASED TRAINING TO IMPROVE LITERACY SKILLS OF TRADITIONAL GAME FOR TOURISM WORKERS
}

\author{
Entoh Tohani $^{1 *}$, Sugito ${ }^{1}$ \\ ${ }^{1}$ Universitas Negeri Yogyakarta \\ Jl. Colombo No. 1, Karangmalang, Depok, Sleman, Yogyakarta 55281, Indonesia
}

\begin{abstract}
This research aims to develop the literacy skills on the traditional game for tourism village workers through experiential-based training. Traditional game literacy is attitudes, knowledge, and skills in managing traditional games to make it more meaningful for life, sustainable, and keep people away from negative social changes. This research is participatory action research and conducted on 25 workers located in the Yogyakarta batik tourism village. Data collected and analyzed by using qualitative methods. The research results showed that the action of skill development able to the target group realized the importance of traditional game literacy in the context of developing tourism services, having the ability to manage tourism services based on traditional games, and forming traditional game tourism management. Therefore, this skill development needs to be carried out continuously and meaningfully by optimizing the involvement of all parties involved in tourism development.
\end{abstract}

Keywords: literacy, games, experiential training, improvement, tourism

How to cite: Tohani, E., \& Sugito, S. (2020). Experiential-based training to improve literacy skills of traditional game for tourism workers. Jurnal Pendidikan Vokasi, 10(1), 3443. doi:https://doi.org/10.21831/jpv.v10i1.28193

*Corresponding Author: Entoh Tohani entoh_tohani@uny.ac.id

Department of Non-Formal Education, Faculty of Education, Universitas Negeri Yogyakarta Jl. Colombo No. 1, Karangmalang, Depok, Sleman, Yogyakarta 55281, Indonesia 


\section{INTRODUCTION}

The development of tourism villages is currently encouraging as employment in the field of tourism can absorb labor and solve the problem of unemployment. In Indonesia, the development reached 1,734 villages spread across Java, Bali, Sumatra, East of Nusa Tenggara, Kalimantan, Papua, and Sulawesi (Putra, 2018). In the long run, it is expected that the community will have income from developing potential in the area to create a prosperous community life that can be started by carrying out productive activities in an area by exploring local wisdom and potential that can be used as a means to increase the income of citizens (Korten, 1986). The tourism village could be interpreted as a form of integration between attractions, accommodation, and supporting facilities that are presented in a structure of community life that integrates with applicable procedures and traditions. An area defined to be a tourist village must consider several factors, including scarcity, naturalness, uniqueness, and community empowerment (Kurniawan \& Prakoso, 2008).

Economically, the presence of tourism villages has an economic impact on the community in the form of expanding employment or vocational opportunities and increasing needs for goods and services (Fennel, 2003; Goeldner \& Ritchie, 2012). One of the impacts is that tourism gives to a variety of vocational activities that could be a source of living income. Activities of tourism can develop jobs related to or support its function, such as tourist scouting, culinary production, accommodation, and hotel services, education, construction, creative industries, etc. (Hiariey \& Sahusilawane, 2013; Hiryanto et al., 2017). These will become opportunities to be entered by members of the community both individually and groups so that they must be prepared to have suitable competencies according to these jobs in the context of effective tourism development.

The development of tourism villages needs to be optimally carried out by utilizing various local wisdoms, both the latent ones and those already manifested in the community. One of the local wisdoms is traditional games that have long been developed in the community. Those games can be a means to provide more meaningful tourism services for visitors. For example, the educational tourism village of Wukirsari, Imogiri, Bantul, besides having batik tourism potential, which is characterized by the presence of 25 batik home industries, it also offers various traditional games such as jaranan, jamuran, engklek, gobak sodor, enggrang, wayang dan payung kertas, kentongan, othok-othok which can be used as another meaningful tourist program for visitors (Tohani \& Sugito, 2019). These games need to be developed so that educational tourism activities become more varied in providing educational nuances that are more exciting and more interesting.

The importance of traditional games, both individual and collective types, is inseparable from the view that the game becomes a means of learning transferability, showing the inculcation of virtue values and the development of positive individual behavior, and as a means of individual entertainment (Blumberg, 2014). According to Chen (2005), games for learning can be studentcentered, develop communicative competence and motivation, reduce learning anxiety, develop creativity, and encourage student participation. Traditional games have the benefit of developing self and community quality. Individual games can improve the values and abilities of sportsmanship, discipline, competition, motoric abilities, conflict resolution, creativity, confidence, logicalcritical-analytical thinking, and achievement (Baek, 2010; White, 2011). Socially, traditional games also become a means of transmitting or preserving culture in the form of values, knowledge, behavior, and artifacts that are conveyed by the previous generation to the next generation. In the end, by improving and developing traditional games, cultural literacy will cultivate the ability to love, understand, develop culture, the ability to be open to learning other cultures and sharing one's own culture, to change personal perspectives, to communicate effectively across cultures, and to act as agents of cultural change (Hirsch et al., 2002).

Unfortunately, in the development of tourism villages, especially those with educational purposes, traditional games' potential has not been managed optimally. Many developing tourism villages offer tourism service programs in the form of natural beauty exploration or ecotourism or only focus on tourism introducing culture, history, and people's lifestyles. In batik education tours, educational tourism activities are manifested in the form of a one-hour program for students in which they can learn to make a batik tulis, starting from the introduction of canting and lorot process to the coloring process (Tohani \& Sugito, 2019). Likewise, other research shows that opti- 
mization of tourism programs based on the use of traditional games has not yet taken place and this game is more widely used in the context of formal education and early childhood education (Anam et al., 2017; Hidayat, 2013; Pramudyani et al., 2017; Sulistyaningtyas \& Fauziah, 2019). Of course, optimizing the use of traditional games in the development of educational tourism villages is determined by the quality of human resources, especially workers of the existing tourism villages. Workers who are competent in managing tourism activities ensure the existing tasks and functions can be carried out effectively, such as learning functions, environmental management, services to visitors, marketing, etc.

Training based on experiential learning as an effort to develop the ability of tourism workers needs to be done with the aim of equipping the workers to have the latest skills and knowledge to manage tourism services and tourism resources they have in order to improve the quality of life for themselves and their communities. It is an educative action to develop individual abilities by understanding, utilizing, and developing experiences owned by individuals, as a result, substance and learning outcomes. In this learning, individuals actively think and transform experiences as a basis for learning (Kolb, 2015). They are involved in feeling, seeing, reflecting, thinking, and acting along with interactions with the environment (experience). This learning emphasizes the internal processes of individuals who transform new and significant experiences and incorporate them in a broader conceptual framework (Beard \& Wilson, 2013; Gonzalez-Perez \& Taras, 2015; Ramsgaard, 2018). The effectiveness of this learning is demonstrated in a number of findings that show experience-based learning for adults can enhance new skills in accordance with the new jobs (Sisselman-Borgia \& Rorino, 2017), professional competence (Istiningrum, 2015; Sepdanius et al., 2018), emotional adult learners (Zeivots, 2016), and improve critical thinking (Heinrich et al., 2015) and communication with others (Alvarez \& Schultz, 2018).

The effectiveness of experiential training depends on the facilitation of learning undertaken by educators. According to Smith \& Betts (2000, in Beard \& Wilson, 2013, p. 18), the learning process can be done with the principle of learning through experience (through), learning about informational (about), and practicing (at work). All three must be associated with the target groups' experiences, such as tourism management, scouting, tourism marketing program practices, interactions in tour groups, etc. Both positive and negative experiences can be used as substances and learning methods. Therefore, facilitation for learning must be developed with the awareness that citizens are individuals who have experiences and can interpret their own experiences so that learning needs to be designed to provide opportunities for learning citizens to interact directly with the environment.

Related to those matters, this research is conducted to develop tourism workers' ability to provide meaningful tourism services for visitors through the implementation of a learning process based on the utilization and development of experiences owned by tourism workers. This learning was done as an instrument to shape their ability to become competent human resources capable of developing tourism services that are meaningful to both individuals and the community.

\section{RESEARCH METHOD}

This research used an action research approach that was intended to develop traditional games' literacy skills for tourism village workers in the context of developing community life through experiential learning. The action research model used was a participatory action research model as it serves as a model of appropriately conducted training in the society life and emphasizes the partnership of actors in empowerment in the learning process or community development. The implementation of activities was cyclical/spiral, namely: understanding issues/ problems, planning actions, implementing actions, and reflecting to improve action plans (McIntyre, 2007). In this study, the intended action was an experience-based training process imposed on the target group. The actions were carried out in one research cycle. Determination of actions must be formulated collaboratively between the researchers and the target group.

Data collection was carried out by interview and observation in accordance with the implementation at each stage of the intended action research. Using the interview guidelines, interviews conducted openly with the tourism village workers, members of the village tourism com- 
munity, educators, members of the suggestion group, and batik craftsmen at the study site. The interview aimed to gather information about tourism village activities, tourism services, manager development needs, tourism opportunities, etc. and conducted individually and in groups/discussions with research subjects by first making a commitment to the interview time and place. Observations were also carried out by researchers assisted by technical staff to find out the activities of tourism management carried out by the target group, the learning process that occurred, the use of traditional games, and the community environment. The researchers used observation guidelines that were previously designed and validated by relevant experts. In collecting data, they worked closely with the head of the target group. During and after the data collection process, the data analyzed using qualitative analysis techniques and emphasized reflection with researchers and the target group.

This action research was conducted from June to August 2019 and located in Wukirsari Village, Imogiri, Bantul Regency. The participants of this study were the workers of Giriloyo (GR) tourism village numbering 25 people. They consisted of 10 men and 15 women who were active and incorporated in the Giriloyo tourism village management association. The selection fell upon this target group due to the presence of those who were active in developing the quality of community life, especially in tourism in the village. The determination of research participants was carried out directly with the village tourism community's management and by considering the willingness and availability of participant time and implementation time.

\section{RESULTS AND DISCUSSION}

The study results can be described by referring to the stages of participatory action research consisting of needs analysis, planning, implementation, and evaluation of learning.

\section{Needs Analysis}

Needs analysis to increase traditional game literacy for village tourism workers in the context of developing meaningful tourism was done by collecting data directly from the target group through interviews and joint discussions. Interviews were conducted with representatives of the target group, community leaders, and batik group administrators by first asking for willingness and agreement for the interview. Discussions were conducted between researchers, target groups, and workers of the tourism village community. The results of data analysis indicated that the target group did not master the ability to manage traditional game literacy although they were directly involved in providing tourist services to visitors. This was observable through the tourism services that they developed lack varieties and rely more on one type of tourism service, namely, batik learning services. In fact, the community environment has a potential based on culture and/or tradition that has not been utilized or integrated into the existing tourism services. One of them is various traditional games within the community, such as engrang, gobak sodor, dakon, etc. The game needed to be developed and deemed relevant to the tourism program to develop tourism services based on tradition and education. They realized that this cultural richness can be put in tour packages for visitors. Lately, traditional games have not been practiced daily, so they deemed it necessary to preserve them. According to the chairman of the association:

Tour visitors are generally students, from schools. Yes, (they) come each month with an average of 500 people, but they only come briefly around an hour, just practice batik, then go home ... They actually want to stay longer, but we have not been able to make another tourism object. Our plan is to make a homestay, traditional outbound game, and educative to increase the amount of income.

In addition, in joint discussions between researchers and target groups, an alternative was discussed, and it was about how to improve the literacy skills of traditional games. Before the agreement, the researchers gave an insight into the importance of developing more productive tourism based on local activities and emphasized the need for traditional games to be developed into an educational tourism package that attracts visitors. Adopting the researchers' view, the target group had a desire to improve its ability to manage tourism services in the city. At the end of the 
discussion, the researchers and the target group agreed that the improvement of traditional game literacy skills should be done in the form of experiential learning.

\section{Planning}

Based on the agreement about the efforts to improve traditional games' literacy through experiential training, researchers worked with representatives of target groups and community leaders to determine learning plans. The researchers first designed a series of learning activities and then presented them to the target group's representatives. In this discussion, group representatives gave feedback, some of them were plan rescheduling, so learning time did not coincide with social activities in the community, resource persons wanted from outside the manager, and requests for the preparation of traditional game equipment. The learning plan prepared by researchers and agreed with the target groups is described in Table 1.

Table 1. Plan on the Experience-Based Training

\begin{tabular}{|c|c|c|c|c|}
\hline Phase & Purpose & Method & Material/Media & $\begin{array}{l}\text { Days to- } \\
\text { / Hour }\end{array}$ \\
\hline$\frac{e^{2}}{e^{2}}$ & $\begin{array}{l}\text { - Building the awareness of target groups } \\
\text { about the potential of traditional games and } \\
\text { tourist services. } \\
\text { - Building agreements and commitments. }\end{array}$ & $\begin{array}{l}\text { Lecture } \\
\text { Brainstorming }\end{array}$ & $\begin{array}{l}\text { HVS paper, } \\
\text { ballpoint, } \\
\text { booknote, } \\
\text { speaker }\end{array}$ & $1 / 4$ \\
\hline \multirow{5}{*}{ 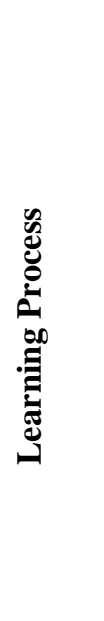 } & $\begin{array}{l}\text { Providing attitudes, knowledge and skills to } \\
\text { the target group regarding the design of } \\
\text { traditional game-based tourism }\end{array}$ & $\begin{array}{l}\text { Lecture } \\
\text { Discussion }\end{array}$ & $\begin{array}{l}\text { Plano paper, } \\
\text { marker, speaker, } \\
\text { module }\end{array}$ & $2 / 8$ \\
\hline & $\begin{array}{l}\text { Providing attitudes, knowledge, and skills to } \\
\text { the target group regarding the ability of } \\
\text { traditional games tour guides }\end{array}$ & $\begin{array}{l}\text { Discussion } \\
\text { Practice } \\
\text { Simulation }\end{array}$ & $\begin{array}{l}\text { Tools used for } \\
\text { traditional } \\
\text { games, module }\end{array}$ & $2 / 6$ \\
\hline & $\begin{array}{l}\text { - Developing guiding skills, design traditional } \\
\text { game-based travel services }\end{array}$ & Assignment & $\begin{array}{l}\text { Tools used for } \\
\text { traditional } \\
\text { games, module }\end{array}$ & $3 / 8$ \\
\hline & $\begin{array}{l}\text { Improving the ability of tour group } \\
\text { management in developing tour services }\end{array}$ & Assignment & $\begin{array}{l}\text { Book note, } \\
\text { ballpoint }\end{array}$ & $3 / 3$ \\
\hline & $\begin{array}{l}\text { - Facilitating target groups in managing } \\
\text { groups }\end{array}$ & Consultation & $\begin{array}{l}\text { Book note, } \\
\text { Ballpoint }\end{array}$ & Tentative \\
\hline 高 & $\begin{array}{l}\text { - Identifying the learning outcomes and } \\
\text { understanding and commitment of the target } \\
\text { group to implement learning outcomes }\end{array}$ & $\begin{array}{l}\text { Joint } \\
\text { reflection }\end{array}$ & $\begin{array}{l}\text { Book note, } \\
\text { ballpoint }\end{array}$ & $4 / 4$ \\
\hline
\end{tabular}

\section{Learning Process}

Experience-based training in order to improve the referred capability was done by stages: awareness, learning, and joint reflection. The awareness phase was carried out by the target group in the form of a joint discussion about the development of GR tourism to a more advanced level through the use of traditional arts and games. The discussion, taking place in a very friendly and warm atmosphere, began with the researchers giving an explanation of the purpose of the discussion and clues about how the tour manager should seize the opportunity, especially with many tourists visiting the batik village of GR. The target groups gave their views alternately based on the participants' knowledge. The discussion results showed the target group realized that the GR environment was very effective in developing the tourism sector in addition to the only and already existing batik tourism. The big potential was traditional markets, batik centers, religious tourism, 
campsites, traditional health centers (gurah), traditional games, etc. These potentials were still undeveloped because they did not have the knowledge and skills to manage these potentials. In addition, the target group also had a strong desire to develop their abilities and hoped for learning opportunities.

The learning process was carried out as planned. The learning process was about innovation in travel. The purpose of this learning was that citizens learn to have the view that in managing tourism, it is necessary to take action or innovative ways so that tourism can develop optimally and provide great benefits. Innovative actions enable economic activities in the tourism sector to become more diverse and provide a large opportunity to earn income. The submission of the material was done by researchers in a family atmosphere and using the local language (Java). The researchers explained the importance of local-potential-based tourism innovation is. He gave an example of innovation in the management of tourism in the form of tourist activities and educational activities, which is popularly known as educative tourism. The researchers also informed the learners that this educative tourism has recently developed in society. The learning was considered a success. This success was concluded when the researchers believed citizens actively learned to understand the concept of innovation in tourism management, as indicated by the comments of a learning resident who agreed with the researchers' view.

Subsequent learning was devoted to developing the literacy skills of batik and traditional games for village workers of batik education tours, followed by experience-based learning conducted by speakers from an experiential learning association. This learning intended to build the target group's understanding of how to formulate tourism programs using traditional arts and games. The learning process was started by the researchers, who opened the learning and conveyed the learning objectives. In this initial learning session, the resource person asked the residents to learn to reflect on what abilities they already had or wanted to have in managing tourism activities. The reflection results were written on four small pieces of paper and displayed by sticking them to a pole in the study room. Various expressions on the results of reflection were seen in the display. For example, there were those who wrote about the wish to be able to communicate well, have the courage to appear in forums, have a stable income, become a reliable tour guide, become a professional, etc.

Following this, the target group was divided into four small groups with five members each. Each group was given a task to study what tourism programs might be developed and how the tourism program's technical implementation would be. In the learning process, the activeness of the participants was reflected in the behavior of each member discussing and giving opinions. The results of the discussion were then presented to other groups by each small group. Researchers' observation showed that each group could produce ideas or program that can be designed, with the examples of the first group conveying their thoughts in the form of tourism activities such as bicycle tours, snacks at traditional markets, homestay, traditional game outbound, etc. including a time plan for the sequence of tourist activities which would be carried out. Other groups also responded to both suggestions and asked questions in this discussion session. For example, members of other groups asked who would train the outbound activities and the possible time if the outbound was conducted. All groups carried out the presentations in turn.

The next lesson was developing the ability to lead tours by using traditional game media present in the surrounding community. In this learning session, the researchers collaborated with speakers who already had experiences in the development of tourism services. Previously, the resource persons in the research introduced various types of games, both individual and group games such as enggrang, dakon, gobak sodor, bakiak, etc. intending to have the target group recall games that were no longer practiced by many community members, build awareness to awaken the cultural heritage in question, and know the great benefits of its existence.

Furthermore, the resource persons also asked them to return to their respective small groups to formulate scenarios for how traditional games were performed for special visitors to the students. The aim of this learning was to make the target group have an effective reference when directly practicing tourism activities that use traditional games. Small group discussions went well where interaction between learning citizens was very communicative. Learning citizens' exchange of opinions was seen in the process of the formulation of scenarios. The results of the discussion were delivered by each small group to other groups in turn. The small group representatives inter- 
acted communicatively what the group produces. Observation on the learning process activities showed that each group was able to create a game implementation scenario as outlined in a cardboard sheet in accordance with their respective assignments. For example, the fifth group provided an overview of the series of implementation of tourism services from the beginning to the end. According to them, visitors were served starting from homestay preparations, touring villages, visits to traditional markets, traditional outbound games, etc. Those activities had a plan on time allocation and their implementation. Each small group produced a plan or scenario for the implementation of tourism that was considered in accordance with environmental conditions. With regard to group results, the resource persons provided input and suggestions so that the scenarios made must be clear and coherent.

The next lesson was to play the role of traditional game tour guides. In this process, each group played the role of a traditional game guide, and the other group members took the role of visitors who can go to the tourist sites based on the scenario that had been made. The role-playing session took place in a pleasant atmosphere, in which those who had never played those traditional games, or those who once had forgotten how to play those traditional games, actively tried to practice the games, which they already had learned during the simulation session. They took turns trying to practice how to lead traditional game tours and use traditional game tools. At the end of the role-play, the resource person gave a view on the guiding practices carried out by small groups. For example, to the groups that stimulated the game grind, the resource person suggested that before starting the game, visitors must be conditioned in advance so they can concentrate, the delivery of game instructions need to be more informative, the guide can give examples, and at the end of the practice moral values of the games should be informed to the visitors. For example, the values imparted by clogs are togetherness, harmony, cooperation and the spirit of never giving up. Visitors should be told about those values after they are engaged in the game. After this session, the resource person emphasized that the target group was expected to be able to practice guiding the tour to visitors in the field by first preparing the equipment and resources needed.

On another day, the learning process occurred in the form of direct practice assignments by the target group. Learning with direct practice assignments was also carried out to develop and improve the learners' skills and ability to carry out outbound to the visitors. The target group members, in accordance with the tourism program that they already mastered, carried out the direct practice independently in the form of forming an outbound division as part of the management of the GR tourism village that aims to promote outbound tourism packages through traditional games, partnering with users, and training or organizing outbound for visitors. The management consisted of a chairman, treasurer, secretary, and members of the division. The division was formed by deliberation mechanism and based on the characteristics and abilities of group members. In addition, the target group was supposed and identified to be able to offer cooperation with junior high schools in the form of outbound implementation.

The learning activities ended with a learning evaluation activity that emphasized the principle of joint reflection. The joint reflection aimed to find out how the learning process could provide positive learning outcomes. This activity was carried out in a friendly atmosphere by forming a circular sitting position in the learning room. The resource person asked participants for their views on the activities they just experienced. Representatives of the participants gave their views alternately about how they felt after participating in this learning session.

\section{Learning Evaluation}

An evaluation of both the process and the results was carried out to make sure that learning of improving literacy skills of traditional games for tourism village workers was successful. Process evaluation was conducted by observing the learning activities of the trainees. The observations showed that the participants were quite enthusiastic about participating in the learning activities. This was evident from the class's pleasant learning atmosphere, especially in small group discussions and simulations of guiding practice of active learning citizens who conveyed opinions and questions both to other learning residents or resource persons, their desire to try games, and the courage in communicating their opinions. 
Learning outcomes were evaluated using interviews with the target group. The interview results show that the target group had an awareness to improve the existing tour programs into programs, including diverse tourism programs and awareness to preserve local culture, understand the motivation to develop outbound tourism through traditional games, and guide tourism through traditional games. The GR Batik community chairman revealed that they were grateful to receive lessons about scouting with traditional games and realized that the potential needed to be put into an attractive tourist service for visitors. The same thing was expressed by a resident of the learning whose initials Dyt that the learning process he participated in was quite fun, especially for residents of his age who were not familiar with traditional games. He believed the learning equipped him with the skills to guide tours utilizing the traditional games. Even an enthusiastically studying female learner revealed that "we are happy to have received this training. We are recalling the past games ... This is an arena for us to strive to preserve culture as a legacy so that it is not extinct".

Learning outcomes also incited a change in the GR batik community group after learning occurred. The change took place to form an association that handled traditional game outbound tourism division as per the agreement with the learning citizens and the association's management. This division was assigned to promote tour packages, especially outbound packages to visitors. Besides, the target group was able to offer visitors the outbound tourism package. One of the proofs of such an ability was an offer of outbound cooperation with a junior high school in Yogyakarta.

\section{Discussion}

The training process carried out toward this research target aimed to equip the targets with attitudes, knowledge, and skills in using traditional games to become learning tools for individuals or groups. This ability is an asset to benefit from opportunities available in the community that has not been used optimally. In order to achieve this goal, experiential-based training became the right approach that allowed the target group to master the expected abilities. The implementation of this learning was using learning methods that led to understanding the target group's experiences, namely joint discussion, brainstorming, simulation practice, and assignments. The changes in the target group's positive behavior showed that the target group mastered the competencies that were expected from the learning process. This proves the hypothesis that learning process can facilitate the target group to form and transform knowledge (Kolb, 2015).

In the context of empowering the community of tourism actors, building individual or community capacity can be done by organizing varied and meaningful experience-based learning according to the needs of the development of local-wisdom-based tourism. Tourism development requires individuals' readiness and ability to plan, manage, and evaluate various tourism activities such as developing tour packages, developing tourism management, developing human resources, and community participation. As a bridge between concepts and theory, the experience used in the development of these abilities needs to be considered and determined better to provide the benefits of continuous learning, challenging, and growing growth (Dewey, 1997). Therefore, experiencebased learning that is humanist, participatory, and focused on developing competencies for tourism management based on local wisdom can be done, such as using community project methods, analyzing the development of empowerment programs, and forming effective learning groups.

The target group's local wisdom is a source of experiences that community developers must recognize as an asset to empower them in advancing tourism activities. This is inseparable from the view that local wisdom contains various latent and manifest potentials that can be utilized to benefit tourism development or other empowerment so that its existence needs to be managed effectively. As a form of ownership of the experience, local wisdom needs to be managed to benefit tourism development. Local wisdom management can begin with how the target group builds awareness of the existence and usefulness of the intended potential objectively, equips itself with the knowledge to manage the potential the local wisdom has, is given the capacity and ability to design the use of local wisdom, and develops abilities to work on the local wisdom. It is recognized that a narrow view, counter-destructive behavior, unwillingness to change, and resistance toward renewal can be an obstacle to individuals who can manage local wisdom. Therefore, efforts are needed to minimize these obstacles and not have a major negative impact on tourism development 
implementation. Thus, from the beginning, it is necessary to carry out an educational process that leads to the formation of individual behavior to continue learning both self and community interests such as conducting focused discussions about the potential and problems faced by the community, planning joint development of tourism, opening forums for sharing experiences, etc.

\section{CONCLUSION}

Based on the results of the activities and discussion, it is concluded that the activity of improving the literacy ability of traditional games for tourism actors in the framework of developing tourism activities becomes one of the empowerment alternatives which, in the end, can create a prosperous society. These development activities can provide positive learning outcomes for learning citizens, including: learning residents have awareness toward their potential and their uses, obtain knowledge and skills in learning visitors through traditional games, and form traditional game tour guide groups. Thus, sustainable empowerment is needed for tourism workers so that tourism development can lead to the development of sustainable tourism based on the use of local potential owned by the community, accompanied by the development of the target group's commitment in carrying out its functions and roles in practicing the ability to guide tourism to visitors.

\section{REFERENCES}

Alvarez, S., \& Schultz, J.-H. (2018). A communication-focused curriculum for dental students - an experiential training approach. BMC Medical Education, 18(1), 55. https://doi.org/10.1186/ s12909-018-1174-6

Anam, S., Ovaleoshanta, G., Ardiansyah, F., \& Santoso, D. A. (2017). Studi analisis budaya permainan tradisional Suku Osing Kabupaten Banyuwangi. SPORTIF, 3(2), 178-191. https://doi.org/10.29407/js_unpgri.v3i2.11911

Baek, Y. (2010). Gaming for classroom-based learning: Digital role playing as a motivator of study. Information Science Reference.

Beard, C., \& Wilson, J. P. (2013). Experiential learning: A best practice handbook for educators and trainers. Kogan Page.

Blumberg, F. J. (2014). Learning by playing: Frontiers of video gaming in education. Oxford University Press.

Chen, I.-J. (2005). Using games to promote communicative skills in language learning. The Internet TESL Journal, 11(2). http://iteslj.org/Techniques/Chen-Games.html

Dewey, J. (1997). Democracy and education. The Pennsylvania State University.

Fennel, D. A. (2003). Ecotourism: An introduction. Routledge.

Goeldner, C. R., \& Ritchie, J. R. B. (2012). Tourism: Principles, practices, philosophies. John Wiley \& Sons.

Gonzalez-Perez, M. A., \& Taras, V. (2015). Conceptual and theoretical foundations: Experiential learning in international business and international management fields. In V. Taras \& M. Gonzalez-Perez (Eds.), The Palgrave handbook of experiential learning in international business (pp. 12-16). Palgrave Macmillan.

Heinrich, W. F., Habron, G. B., Johnson, H. L., \& Goralnik, L. (2015). Critical thinking assessment across four sustainability-related experiential learning settings. Journal of Experiential Education, 38(4), 373-393. https://doi.org/10.1177/1053825915592890

Hiariey, L. S., \& Sahusilawane, W. (2013). Dampak pariwisata terhadap pendapatan dan tingkat kesejahteraan pelaku usaha di kawasan wisata Pantai Natsepa, pulau Ambon. Jurnal Organisasi Dan Manajemen, 9(1), 87-105. https://jurnal.ut.ac.id/index.php/jom/article/ view/40 
Hidayat, D. (2013). Permainan tradisional dan kearifan lokal Kampung Dukuh Garut Selatan Jawa Barat. Jurnal Academica Fisip Untad. JURNAL ACADEMICA Fisip Untad, 5(2), 1057-1070. http://jurnal.untad.ac.id/jurnal/index.php/academica/article/view/2244

Hirsch, E. D., Kett, J. F., \& Trefil, J. (2002). The new dictionary of cultural literacy: What every American needs to know. Houghton Mifflin.

Hiryanto, H., Wibawa, L., \& Tohani, E. (2017). Dampak ekonomi dan sosial wisata alam berbasis masyarakat dalam konteks pemberdayaan masyarakat: Studi kasus pada Desa Wisata Bejiharjo, Kec. Karangmojo, Kab. Gunungkidul. Jurnal Penelitian Ilmu Pendidikan, 10(2), 149-160. https://doi.org/10.21831/jpipfip.v10i2.17908

Istiningrum, A. A. (2015). Efektivitas Open-Ended Experiential Learning Cases dalam peningkatan pertimbangan profesional. Jurnal Cakrawala Pendidikan, 34(1), 47-57. https://doi.org/ 10.21831/cp.v1i1.4175

Kolb, D. A. (2015). Experiential learning: Experience as the source of learning and development. Pearson Education.

Korten, D. C. (1986). Community management: Asian experiences and perspectives. Kumarian Press.

Kurniawan, A., \& Prakoso, B. S. E. (2008). The influence of spatial urbanization to regional condition in periurban areas of Yogyakarta. Forum Geografi, 22(1), 27-43. https://doi.org/ 10.23917/forgeo.v22i1.4924

McIntyre, A. (2007). Participatory action research. SAGE Publications.

Pramudyani, A. V. R., Kurniawan, M. R., Rasyid, H., \& Sujarwo, S. (2017). Kurikulum holistik integratif berbasis permainan tradisional pada PAUD di Yogyakarta. Jurnal Penelitian Ilmu Pendidikan, 10(2), 86-96. https://doi.org/10.21831/jpipfip.v10i2.17910

Putra, D. A. (2018). Data BPS: Indonesia miliki 1.734 desa wisata. Merdeka.Com. https:// www.merdeka.com/uang/data-bps-indonesia-miliki-1734-desa-wisata.html

Ramsgaard, M. B. (2018). Experiential learning philosophies of enterprise and entrepreneurship education. In D. Hyams-Ssekasi \& E. F. Caldwell (Eds.), Experiential learning for entrepreneurship: Theoretical and practical perspectives on enterprise education. Palgrave Macmillan.

Sepdanius, E., Afriani, R., \& Komaini, A. (2018). Standarization of experiential learning facilitator in West Sumatera. Jurnal Cakrawala Pendidikan, 37(2), 294-305. https://doi.org/10.21831/ cp.v37i2.19745

Sisselman-Borgia, A. G., \& Rorino, G. C. (2017). Innovations in experiential learning for adult learners. Journal of Applied Learning in Higher Education, 7(Spring), 3-13. https://www. missouriwestern.edu/appliedlearning/wp-content/uploads/sites/116/2018/11/JALHE-7.pdf

Sulistyaningtyas, R. E., \& Fauziah, P. Y. (2019). Pengembangan buku panduan permainan tradisional untuk meningkatkan kemampuan motorik kasar anak usia 5-6 tahun. JPPM (Jurnal Pendidikan Dan Pemberdayaan Masyarakat), 6(1), 50-58. https://doi.org/10.21831/ jppm.v6i1.23477

Tohani, E., \& Sugito, S. (2019). Innovation needs, social capital, and learning process of batik craftsmen. Jurnal Economia, 15(1), 17-33. https://doi.org/10.21831/economia.v15i1.22799

White, J. (2011). Playing and learning outdoors: Making provision for high-quality experiences in the outdoor environment. Routledge.

Zeivots, S. (2016). Emotional highs in adult experiential learning. Australian Journal of Adult Learning, 56(3), 353-373. https://www.ajal.net.au/emotional-highs-in-adult-experientiallearning/ 